\title{
Discriminant analysis in the selection of groups of peach cultivars
}

\author{
G.W. Melo 1 ,a, D.E. Rozane ${ }^{2}$, G. Brunetto ${ }^{3}$ and D.S. Lattuada ${ }^{4}$
}

1Empresa Brasileira de Pesquisa Agropecuária, Bento Gonçalves, Rio Grande do Sul, Brazil; ${ }^{2}$ Universidade Estadual Paulista "Júlio de Mesquita Filho", Registro, São Paulo, Brazil; ${ }^{3}$ Federal University of Santa Maria, Santa Maria, Rio Grande do Sul, Brazil; ${ }^{4}$ Research Center Celeste Gobbato, Caxias do Sul, Rio Grande do Sul, Brazil.

\begin{abstract}
Brazil ranks $14^{\text {th }}$ in the world in terms of peach and nectarine production. Of the nearly 211,000 tons total output, the state of Rio Grande do Sul produces $60 \%$ of the national production, while southern Brazil accounts for $75 \%$. This indicates that adequate parameters are required to manage the nutritional status of all fruit trees, of which the peach tree is an important component, as well as the performance of long-term experiments under field conditions in several, but often restricted, numbers of cultivars. The nutritional parameters that have been established as adequate can be applied to other cultivars which reveal similar nutritional contents and equivalent demands. Besides productivity, 12 elements $(\mathrm{N}, \mathrm{P}, \mathrm{K}, \mathrm{Ca}, \mathrm{Mg}, \mathrm{S}, \mathrm{Cu}, \mathrm{Fe}$, $\mathrm{Mn}, \mathrm{Zn}, \mathrm{Al}$ and $\mathrm{Na}$ ) were analyzed in leaf tissue samples in 144 commercially cultivated peach orchards in South Rio Grande do Sul, specifically the cultivars of Chimarrita, Chiripá, Delanona, Eragil, Fascínio, Kampai, Pialo, PS10711, PS-Tardia and São Barbosa. Group analysis employing the Wilks' Lambda test $(F=9.29 ; p<0.01)$ revealed differences among the groups. Nutrients like $\mathrm{Cu}, \mathrm{Zn}, \mathrm{K}, \mathrm{Mg}$, $\mathrm{Ca}$ and $\mathrm{N}$ were found to most significantly influence growth and formed the three main axes for distinguishing among the groups, whereas nutrients like $S, P$ and $M n$, showed the least contribution. The nutritional profiles of the peach cultivars can be categorized in homogeneous groups to benefit from the fertilizer trials. Cluster analysis can be instrumental in the diagnosis and nutrient management of peach trees.
\end{abstract}

Keywords: Prunus persica, fruit, nutrition, compositional nutrient

\section{INTRODUCTION}

The global peach and nectarine production over the last decade (2004-2014) revealed a $35.9 \%$ increase, achieving 22.8 million $t$ across 1.5 million ha in 2014 . With respect to world production, in 2014 Brazil contributed $0.9 \%$, and was ranked fourteenth, in terms of volume. Brazil's output was 211.1 thousand t, across 18.2 thousand ha, or about $11.6 \mathrm{t} \mathrm{ha}^{-1}$; China, Spain and Italy, which also have the highest yields, at levels of 17.1 to $18.5 \mathrm{t} \mathrm{ha}^{-1}$ (FAO, 2017).

According to the Brazilian Institute of Geography and Statistics (IBGE, 2017) the state of Rio Grande do Sul, in 2015, registered the highest peach production of $128,900 \mathrm{t}$, after which ranked São Paulo (35,954 t) and Santa Catarina (21,700 t). However, in the same year, the output of the biggest producer State dropped to $10.3 \mathrm{t} \mathrm{ha}^{-1}$, less than the global and national averages of 15.2 and $12.4 \mathrm{t} \mathrm{ha}^{-1}$, respectively. Besides, it was $135 \%$ below the average productivity recorded in the State of São Paulo, which held the highest ranking for the Brazilian average (IBGE, 2017). Thus, it is evident that although the State of Rio Grande do Sul shows strong preference for cultivation, it is crucial that production technologies are improved.

In light of this data, it is of fundamental importance to ascertain the nutritional characteristics of the plants, not only to study the direct influence on productivity, but also because it affects the fertilization practices, which cost the State of Rio Grande do Sul approximately $20 \%$ of the production expenses incurred for the cultivation in regions of

${ }^{\mathrm{a} E}$-mail: wellington.melo@embrapa.br 
stable production (>8 years) (Agrianual, 2017). Although such significant expenses are being met for fertilization practices during cultivation, the scientific parameters that drive them are supported by very few long-term experiments, performed under field conditions. Besides, in most cases, these studies are often limited to specific cultivars and edaphoclimatic conditions.

In this study, the experiments have been done to identify the reference values for the cultures, obtain standards, meaning the nutritional constituents regarded as fitting for compensatory harvests. The assumption is that despite the nutrients being interrelated, the influence that a nutrient exerts on crop yield is dependent upon the proximity of other nutrients in the right proportions. Therefore, all the nutrients except those being studied are assumed to be adequate.

However, the method of obtaining satisfactory levels of a specific nutrient in the calibration experiments was criticized, because it failed to account for the interactions among the various nutrients, as numerous such interrelationships exist in plants (Prevot and Ollagnier, 1956; Marschner, 1995; Parent, 2011). Thus, an alteration in one constituent will influence the percentages of the others, because uncorrelated proportions are not automatically independent correlations (Prevot and Ollagnier, 1956; Thomas and Aitchison, 2006).

It must be recognized that the adequate nutritional balance affects the characteristics of each genotype, as well as the edaphoclimatic conditions that are being controlled. Sharpe et al. (1989) reported that the nutritional status assessed at different times affected the nutrient balance of the peach tree grown in the United States. This concurs with observations made under Brazilian conditions for guava cultivation (Rozane et al., 2015b). However, at the same time, the assessment of the nutritional status of a crop under similar edaphoclimatic conditions reveals divergences in the nutritional balance within the crop when variations are present in the cultivar/variety, as reported by Parent et al. (2013b) and Rozane et al. (2015b) on mango Rozane et al. (2015a) in orange trees and Botelho et al. (2010) in pear trees. This implies that standards should be identified and set for nutrient balance at the species level for cultivation under each specific edaphoclimatic condition.

However, although divergences between the nutritional patterns of each species, cultivar and edaphoclimatic cultivation condition are evident, the similarities in the nutritional patterns among the genotypes should also be taken into consideration (Parent et al., 2013a; Rozane et al., 2015a). Thus, it must be recognized that the nutritional parameters that are already regarded as suitable, can be transferred to other cultivars, which possess nutritional contents and correspondent demands.

This study aimed at assessing the formation of groups of cultivars having similar nutrient profiles, in order to achieve uniform nutrient management. This will enable the transfer of knowledge gained from expensive fertilizer trials performed for one cultivar to other cultivars having the same nutritional profile.

\section{MATERIAL AND METHODS}

A total of 144 commercial peach orchards (Prunus persica), in production in the Serra Gaúcha region of Rio Grande do Sul, southern Brazil, were found between the coordinates of $29^{\circ} 08^{\prime} 47^{\prime \prime} \mathrm{S}$ latitude and $51^{\circ} 31^{\prime} 17^{\prime \prime} \mathrm{W}$ longitude, at an altitude of $208 \mathrm{~m}$. The orchards, with an average age of nine years per plot, were planted with different peach cultivars, viz. 'Chimarrita', 'Chiripá', 'Delanona', 'Eragil', 'Fascínio', 'Kampai', 'Pialo', 'PS10711', 'PS-Tardia' and 'São Barbosa'. The plants were managed under drastic pruning measures trained as open centre, maintaining an average row spacing of $4.00 \mathrm{~m}$ and spacing between plants of $2.00 \mathrm{~m}$. The climatic condition of the region based on the Koeppen classification is Cfa.

Using a composite sheet, the sample the plots were represented by groups of 25 single leaf samples. In each plant, the sampling of complete leaves (limbus + petiole) was done by collecting the leaves from the medial part of the branches produced in the year, from the cardinal points (east, west, north, south), in 2 weeks prior to the start of fruit harvest. This was performed according to the method recommended by the Commission of Chemistry and Soil Fertility of the States of Rio Grande do Sul and Santa Catarina (CQFS-RS/SC, 2016). 
Washing of the sheets was performed in the following sequence: first in running water, then in a solution of deionized water and neutral detergent $(0.1 \%)$, next with a solution of deionized water and hydrochloric acid $(0.3 \%)$ and finally in deionized water. The leaves were then oven-dried in a forced air ventilation oven at $60 \pm 5^{\circ} \mathrm{C}$ until constant mass was achieved. Then they were subjected to grinding in a Wiley mill, which included a $0.841 \mathrm{~mm}$ (20 mesh) sieve, and set aside. The tissue was subjected to digestion (Tedesco et al., 1995). The $\mathrm{N}$ content was determined using the micro-Kjeldahl apparatus, $\mathrm{P}$ through colorimetry, $\mathrm{K}$ and $\mathrm{Na}$ in a flame photometer, and the $\mathrm{Ca}, \mathrm{Mg}, \mathrm{S}, \mathrm{Cu}, \mathrm{Fe}, \mathrm{Mn}, \mathrm{Zn}$ and $\mathrm{Al}$ contents by atomic absorption spectrophotometry. harvest.

The plant yield in each field was calculated by the weight of all the fruits at the time of

The consistency of the descriptors used to confirm the differences among the cultivars $(n=10)$ were the elements that were assessed and their productivity $(n=13)$, applying the Wilk's Lambda test. For application of the multivariate analyses, standardization of the data set was done, and each descriptor was assigned a null mean and unit variance. The cluster analysis was performed based on the method advocated by Sneath and Sokal (1973) based at Euclidean distance, similar to the coefficient of similarity between pairs of places and the coefficient of dissimilarity, utilizing the geometric distance in a multidimensional space. Therefore, the lesser the distance between two places, the greater their similarity depending on the descriptors considered.

The eigenvalues determined indicate the percentage of variance described by each attribute; therefore, the criterion adopted to select the number of components was to pick only those that showed eigenvalues more than 1.00 and synthesize an accumulated variance of more than $70 \%$ (Hair et al., 2009). Thus, the first major components normally illustrate a major portion of the variance of the original variables. This analysis facilitated minimizing the space of the original variables in a smaller set, while retaining the maximum amount of the original variability of the data. The discriminant analysis was then applied to this set, based on the method proposed by Kleka (1975) and Engelman (1997).

Employing the multivariate analysis of variance, this procedure was followed to analyze the ten cultivars with the attributes under study and confirmed if the significance of the variables analyzed together showed any difference when each of them (elements + productivity) were compared among themselves. If it were possible to ascribe similarities between canonical groups, if $\mathrm{p}<0.01$, then $\mathrm{H} 0$ needed to be rejected; this lead to the assumption that differences existed among the cultivars (Aitchison, 1986). All the multivariate statistical analyses were processed using STATISTICA software version 7.0 (StatSoft, 2004).

\section{RESULTS AND DISCUSSION}

The findings from the Wilk's Lambda test applied to the groups of cultivars revealed: $\mathrm{W}-\mathrm{L}=0.0030062 ; \mathrm{F}=9.2919 ; \mathrm{p}<0.0001$, thus rejecting $\mathrm{H} 0$, and acknowledging the differences among the cultivars.

The data in Table 1 confirm the significance of each variable and its contribution to the total variance of the descriptors related to the variable elements and productivity.

Although a significant explanation for Root $7(\mathrm{p}<0.01)$ was available, Hair et al. (2009) indicated the necessity to select eigenvalues above 1.00 and were able to synthesize a cumulative variance above $70 \%$; this signifies Root 3, for the present study, which accounts for $79 \%$ of the cumulative variance (Table 1 ).

The attributes that appear most remarkable in Root 1 are $\mathrm{Cu}$ and $\mathrm{Zn}$, followed by $\mathrm{K}$ and $\mathrm{Mg}$, suggesting that the maximum expression of the variance of the first eigenvalue is illustrated by the micronutrients, which are found in surplus or overabundance; this is true particularly in 'Delanona' for $\mathrm{Cu}$ and $\mathrm{Zn}$ and in 'PS-Delay' for Zn (Figure 1e, g), when compared with the recommendation of CQFS-RS/SC (2016), that the contents> $50 \mathrm{mg} \mathrm{kg}^{-1}$ present for both micronutrients are in excess. A surfeit of K content is seen in 'Eragil' (Figure $1 \mathrm{~b}$ ), as well as large variations in the Mg content (Figure 1d). Rozane et al. (2015a) in their study on citrus fruits reported the presence of excess $\mathrm{Cu}$ and $\mathrm{Zn}$ in the fruit tissue samples of 
these plants. This detection in the evaluation of the diagnosis, indicated that such excessive micronutrient contents may result from the applications of various types of pesticides and, therefore, reflect the degree of need by the genotypes for superior pathogen management, than for nutritional requirements.

Table 1. Discriminant analysis of the descriptors that constitute the attributes assessed for the peach genotypes evaluated.

\begin{tabular}{lcccccccc}
\hline Variable & Root 1 & Root 2 & Root 3 & Root 4 & Root 5 & Root 6 & Root 7 & Root 8 \\
\hline $\mathrm{N}$ & -0.11 & 0.57 & -0.55 & -0.70 & 0.21 & 0.41 & 1.16 & 0.27 \\
$\mathrm{P}$ & 0.24 & 0.24 & -0.06 & -0.52 & 0.54 & 0.06 & -2.16 & -0.82 \\
$\mathrm{~K}$ & -0.75 & 0.46 & 1.12 & -0.06 & -0.08 & 0.52 & -0.30 & 0.22 \\
$\mathrm{Ca}$ & -0.53 & 1.00 & -1.40 & 0.69 & 0.47 & -0.04 & 0.82 & -0.03 \\
$\mathrm{Mg}$ & 0.65 & -0.18 & 0.55 & -1.43 & -0.26 & 0.80 & -0.61 & 0.20 \\
$\mathrm{~S}$ & 0.11 & 0.04 & 018 & -0.12 & 0.13 & 0.12 & 0.05 & 0.06 \\
$\mathrm{Cu}$ & 1.29 & 0.55 & 0.52 & 0.23 & 0.16 & 0.13 & 0.09 & -0.01 \\
$\mathrm{Fe}$ & 0.58 & -0.50 & -0.18 & 0.51 & -0.25 & 0.74 & 0.30 & -0.49 \\
$\mathrm{Mn}$ & -0.33 & 0.22 & -0.34 & -0.49 & -0.61 & -0.12 & -0.88 & -0.22 \\
$\mathrm{Zn}$ & -1.27 & 0.45 & 0.20 & -0.06 & -0.21 & 0.00 & 0.47 & -0.30 \\
$\mathrm{Na}$ & 0.12 & -0.18 & 0.63 & 0.15 & -0.04 & 0.15 & 0.08 & 0.50 \\
$\mathrm{Al}$ & 0.44 & -0.11 & -0.05 & -0.47 & 0.00 & $-0,67$ & 0.19 & 0.55 \\
$\mathrm{Productivity}$ & 0.31 & -0.29 & 0.46 & -0.19 & -0.54 & -0.18 & -0.11 & -0.34 \\
\hline Eigenval & 4.08 & 2.90 & 1.75 & 0.87 & 0.56 & 0.50 & 0.23 & 0.11 \\
Cum. Prop & 0.37 & 0.63 & 0.79 & 0.87 & 0.92 & 0.97 & 0.99 & 1.00 \\
Canonicl R & 0.90 & 0.86 & 0.80 & 0.68 & 0.60 & 0.58 & 0.44 & 0.31 \\
Wilks' Lambda & 0.003 & 0.015 & 0.060 & 0.163 & 0.306 & 0.478 & 0.718 & 0.887 \\
Chi-Sqr & 763.63 & 549.97 & 370.99 & 238.13 & 155.59 & 97.07 & 43.53 & 15.79 \\
Significance, $\mathrm{p}$ & $<0.0001$ & $<0.0001$ & $<0.0001$ & $<0.0001$ & $<0.0001$ & $<0,0001$ & 0.003 & 0.201 \\
\hline
\end{tabular}

The eigenvalues recorded for Roots 2 and 3 show a clearer indication of the nutritional differences. Among the variables assessed, the nutrients $\mathrm{Ca}, \mathrm{N}, \mathrm{Cu}, \mathrm{Fe}, \mathrm{K}$ and $\mathrm{Na}$ reveal relevance (Figure 1). The Ca contents for 'PS-Late' and 'São Barbosa' (Figure 1c) compared to the other cultivars exceeded the maximum limit acceptable for the crop, while the N (Figure 1a) in all the cultivars fell to below normal, according to the recommendation of CQFS-RS/SC (2016).

Only the 'Fascinium' and PS10711 revealed a mean Fe content in the plant population (Figure 1f) which satisfied the requirements of the CQFS-RS/SC (2016), while the results for $\mathrm{Na}$ (Figure $1 \mathrm{~h}$ ) revealed great amplitude in the determinations, particularly for 'Eragil'.

Figure 2 shows the Wilk's Lambda test applied to Roots 1, 2 and 3 reveal differences between the genotypes evaluated (Figure 2), confirming, for the variables studied, the general indications of Hair et al. (2009), in synthesizing the accumulated variance above $70 \%$ (Figure 2).

The associations of each genotype in each root are shown in Figure 2, facilitating the identification of the similarities or divergences of each cultivar, taking into account the weight of the contribution made by each variable (Table 1 ).

The two discriminant functions, as shown in Figure 3, expressed 63\% of the variance, and the contribution of the descriptors is related to $\mathrm{Cu}, \mathrm{Zn}$ and $\mathrm{Ca}$ and $\mathrm{Fe}$, respectively, in Roots 1 and 2 (Table 1).

Apart from Figure 3, the correlation matrix of the attributes evaluated in Roots 1, 2 and 3 are shown in Table 2, where the differences between each genotype are evident when the value is $<0.01$; this indicates similarities between 'Chimarrita' and the genotypes 'Cripripá', 'Kampai' and 'Pialo'; 'Chiripá' and 'Kampai'; 'Fascination' and 'PS1071'; besides 'Kampai' and 'Pialo'. 

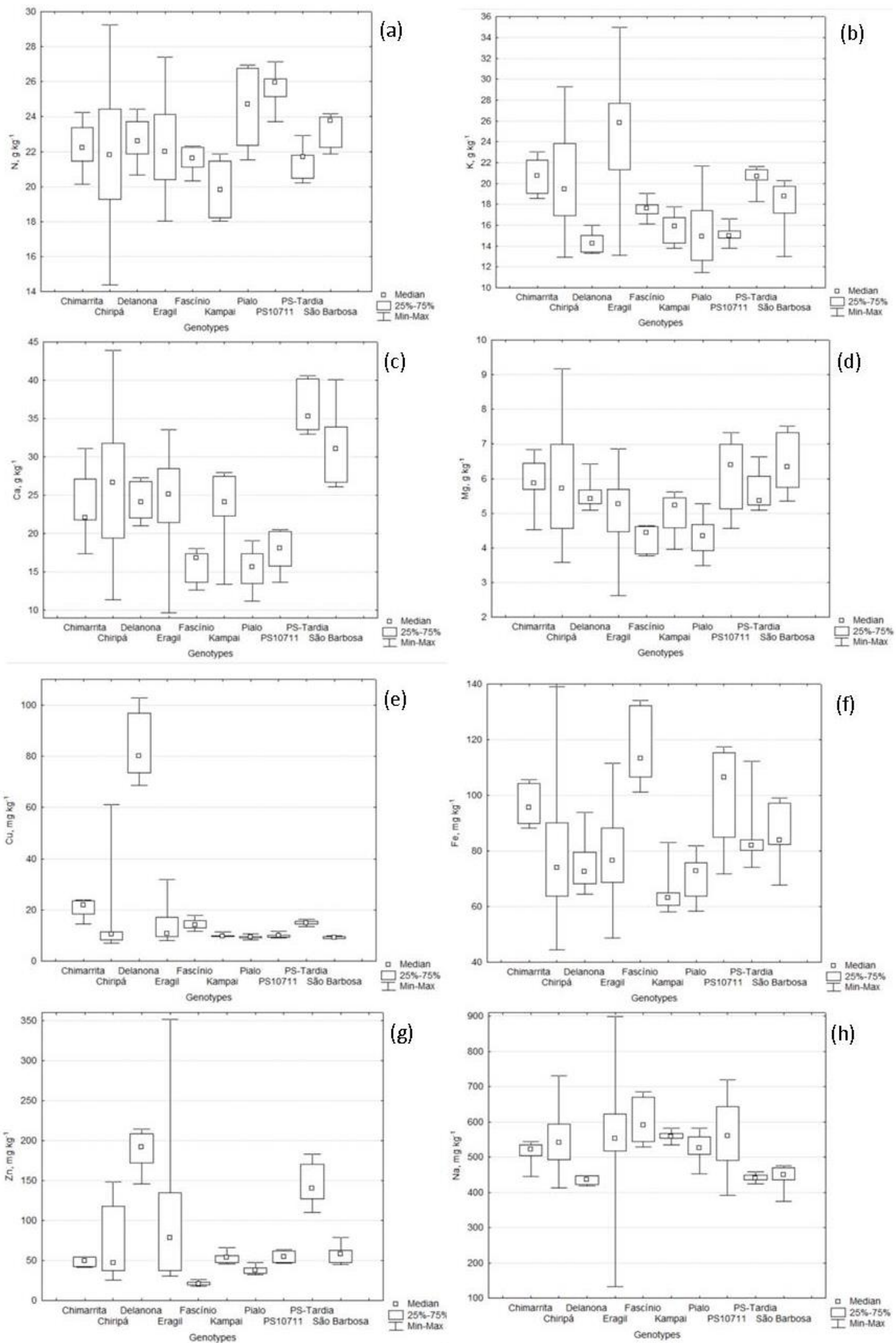

Figure 1. Box plots of leaf contents of nitrogen (a), potassium (b), calcium (c), magnesium $(d)$, copper (e), iron (f), zinc (g) and natrium (h) for the peach trees. 


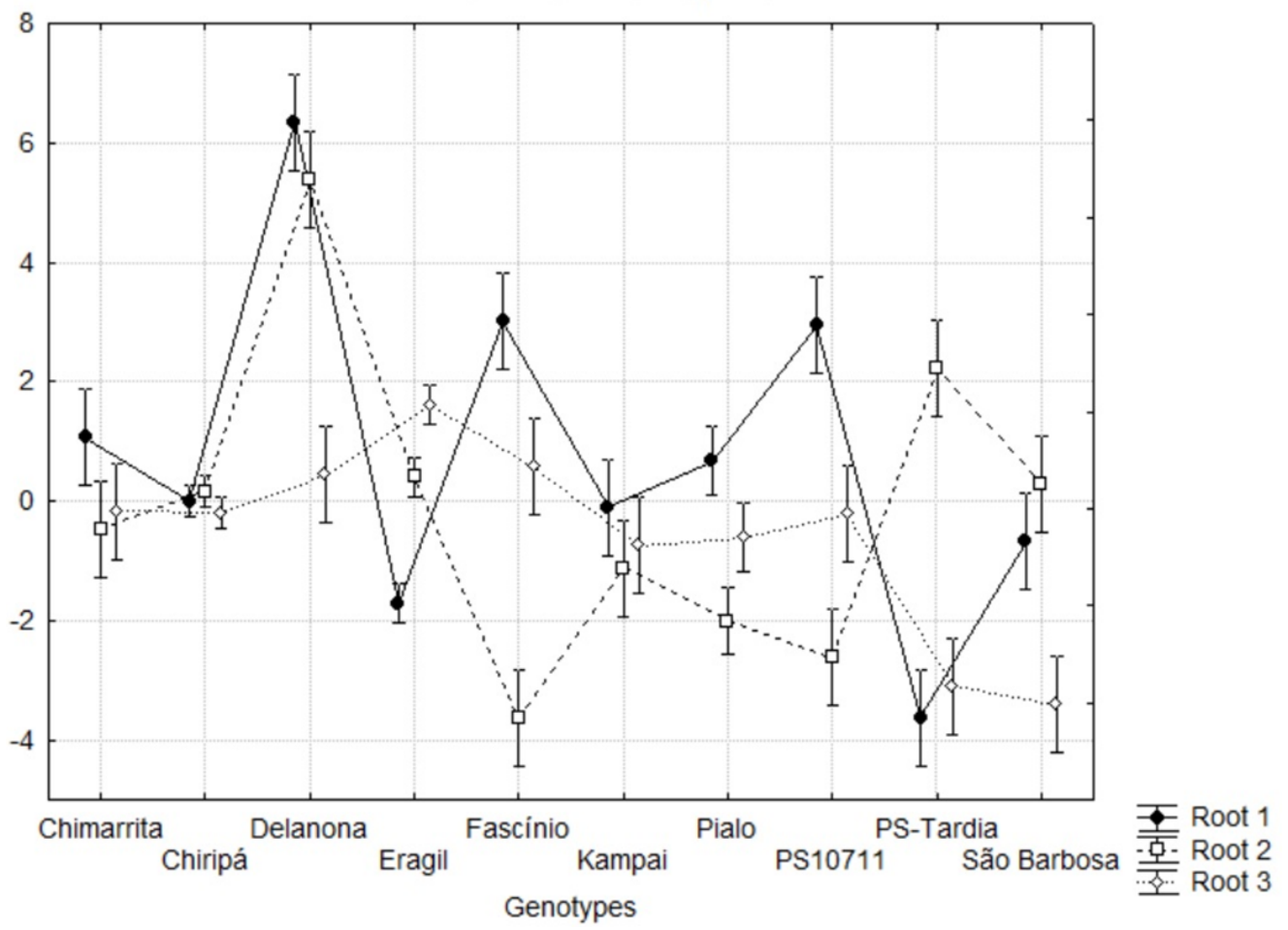

Figure 2. Proportion of variation of Roots 1, 2 and 3 of the data set of the discriminant analysis of the peach genotypes.

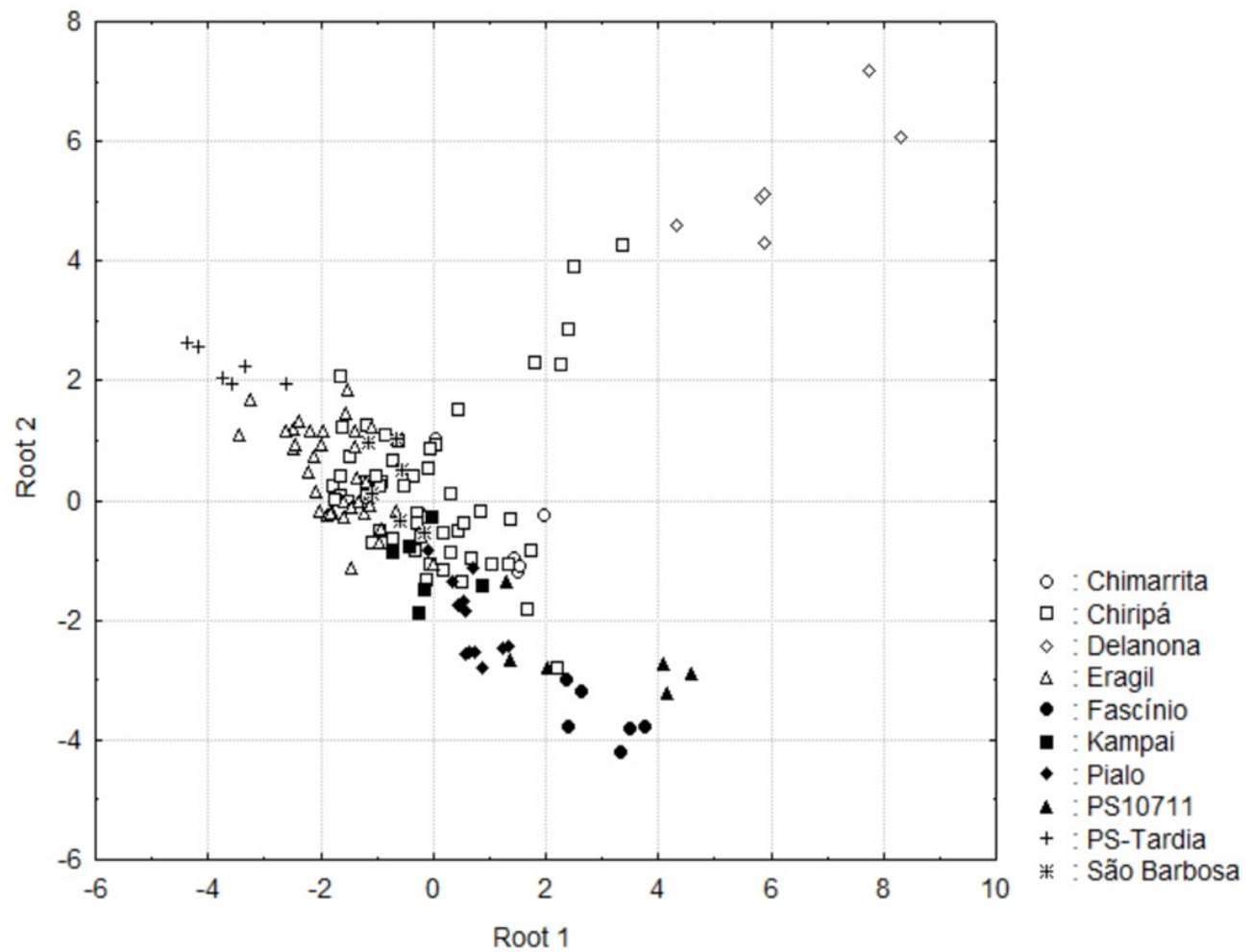

Figure 3. Graphical dispersion of the discriminant population analysis of the 10 peach genotypes studied. 
Table 2. Correlation matrix (Pearson) of the attributes evaluated in Roots 1, 2 and 3 among the 10 peach genotypes studied.

\begin{tabular}{|c|c|c|c|c|c|c|c|c|c|}
\hline Genotypes & Chiripá & Delanona & Eragil & Fascínio & Kampai & Pialo & PS10711 & PS-Tardia & São Barbosa \\
\hline Chimarrita & 0.05 & 0.00 & 0.00 & 0.00 & 0.10 & 0.02 & 0.00 & 0.00 & 0.00 \\
\hline Chiripá & & 0.00 & 0.00 & 0.00 & 0.02 & 0.00 & 0.00 & 0.00 & 0.00 \\
\hline Delanona & & & 0.00 & 0.00 & 0.00 & 0.00 & 0.00 & 0.00 & 0.00 \\
\hline Eragil & & & & 0.00 & 0.00 & 0.00 & 0.00 & 0.00 & 0.00 \\
\hline Fascínio & & & & & 0.00 & 0.00 & 0.18 & 0.00 & 0.00 \\
\hline Kampai & & & & & & 0.14 & 0.00 & 0.00 & 0.00 \\
\hline Pialo & & & & & & & 0.00 & 0.00 & 0.00 \\
\hline PS10711 & & & & & & & & 0.00 & 0.00 \\
\hline PS-Tardia & & & & & & & & & 0.00 \\
\hline
\end{tabular}

\section{CONCLUSIONS}

The following conclusions can be drawn from the study:

- The nutritional profiles of the peach cultivars can be categorized in homogeneous groups to benefit from the fertilizer trials.

- Cluster analysis can be instrumental in the diagnosis and nutrient management of the peach trees.

\section{Literature cited}

Agrianual. (2017). Anuário da Agricultura Brasileira, 1'st edn (São Paulo, Brazil: FNP), pp.432.

Aitchison, J. (1986). The Statistical Analysis of Compositional Data (London, United Kingdom; New York, USA: Chapman and Hall), pp.416.

Botelho, R.V., Müller, M.M.L., Basso, C., and Suzuki, A. (2010). Estado nutricional de diferentes cultivares de pereira nas condições edafoclimáticas de Guarapuava-PR. Rev. Bras. Frutic. 32 (3), 884-891 https://doi.org/10.1590/S0100-29452010005000087.

Comissão de Química e Fertilidade do Solo (CQFS-RS/SC). (2016). Manual de Adubação e Calagem para os Estados do Rio Grande do Sul e de Santa Catarina (Porto Alegre: SBCS Núcleo Regional Sul/UFRGS), pp.375.

Engelman, L. (1997). Discriminant analysis. In Systat 7.0 Statistics, L. Wilkinson, ed. (USA: Chicago Press), pp.751.

Food and Agricultural Organization. (2017). www.fao.org.

Hair, J.F., Black, W.C., Babin, B.J., Anderson, R.E., and Tatham, R.L. (2009). Análise Multivariada de Dados, $6^{\text {th }}$ edn (Porto Alegre, Brazil: RS Bookman), pp.688.

Instituto Brasileiro de Estatística (IBGE). (2017). www.ibge.gov.br.

Kleka, W.R. (1975). Discriminant Analysis: Quantitative Application in the Social Science (California, USA: University of California), pp.72.

Marschner, H. (1995). Mineral Nutrition of Higher Plants (San Diego, CA, USA: Academic Press), pp.889.

Parent, L.E. (2011). Diagnoses the nutriente compositional space of fruit crops. Rev. Bras. Frutic. 33 (1), 321-334 https://doi.org/10.1590/S0100-29452011000100041.

Parent, S.E., Parent, L.E., Egozcue, J.J., Rozane, D.E., Hernandes, A., Lapointe, L., Hébert-Gentile, V., Naess, K., Marchand, S., Lafond, J., et al. (2013a). The plant ionome revisited by the nutrient balance concept. Front Plant Sci 4, 39 https://doi.org/10.3389/fpls.2013.00039. PubMed

Parent, S.E., Parent, L.E., Rozane, D.E., and Natale, W. (2013b). Plant ionome diagnosis using sound balances: case study with mango (Mangifera indica). Front Plant Sci 4, 449 https://doi.org/10.3389/fpls.2013.00449. PubMed

Prevot, P., and Ollagnier, M. (1956). Methode d'utilization du diagnostic foliarie. In Plant Analysis and Fertilizer Problems (Paris, France: Institut de Recherches pour les Huiles et Oléagineux (IRHO)), p.177-192.

Rozane, D.E., Mattos, D., Jr., Parent, S.E., Natale, W., and Parent, L.E. (2015a). Meta-analysis in the selection of groups in varieties of citrus. Commun. Soil Sci. Plan. 46 (15), 1948-1959 https://doi.org/10.1080/ 00103624.2015 .1069307$. 
Rozane, D.E., Parent, L.E., and Natale, W. (2015b). Evolution of the predictive criteria for the tropical fruit tree nutritional status. Científica (Jaboticabal) 44 (1), 102-112 https://doi.org/10.15361/19845529.2016v44n1p102-112.

Sharpe, R.R., Reilly, C.C., Nyczepir, A.P., and Okie, W.R. (1989). Comparison of elemental concentrations between peach tree short life and healthy trees before and after tree death. Commun. Soil Sci. Plan. 20 (17-18), 1753-1767 https://doi.org/10.1080/00103628909368181.

Sneath, P.H., and Sokal, R.R. (1973). Numerical Taxonomy: the Principles and Practice of Numerical Classification, W.H. Freeman, ed. (San Francisco, USA: International Association for Plant Taxonomy), pp.573.

StatSoft 2004 - STATISTICA. (2004). Data Analysis Software System, Version 7. www.statsoft.com.

Tedesco, M.J., Gianello, C., and Biassani, C.A. (1995). Análise de Solo, Plantas e Outros Materiais, $2^{\text {nd }}$ edn (Porto Alegre, Brazil: Universidade Federal do Rio Grande do Sul), pp.174.

Thomas, C.W., and Aitchison, J. (2006). Log-ratios and geochemical discrimination of Scottish dalradian limestones: a case study. In Compositional Data Analysis in the Geosciences: From Theory to Practice, A. Buccianti, G. Mateu-Figueras, and V. Pawlowsky-Glahn, eds. (London, UK: Geological Society), p.25-41. 